\title{
The initial years of the implementation of the Basic Education Assistance Module in Zimbabwe: 2001-2005
}

\author{
Florence Mutasa \\ Dept. of Politics and Public Management, Midlands State University \\ P. Bag 9055, Gweru, Zimbabwe \\ E-mail: missfmutasa@gmail.com
}

Accepted: April 11, 2015

Doi:10.5296/ jpag.v5i2.7328 URL: http://dx.doi.org/10.5296/ jpag.v5i2.7328

\begin{abstract}
Illiteracy is thought to be one of the biggest causes of the poverty cycle. Thus education is perceived as a tool of breaking the poverty cycle. Literature on poverty also advocates bottom-up participatory approaches to development as a lasting solution to poverty alleviation Hence, BEAM is one of the programmes that the Government of Zimbabwe put in place to improve the conditions of the majority blacks through education with the involvement of communities in the identification of intended beneficiaries. The objective of the research is to assess the effectiveness of BEAM as a poverty alleviation strategy. Through the review of literature and interviews, a general overview of the concept of beneficiary participation (an important component of BEAM) is given and the initial years of the implementation of BEAM is assessed. Results of the study indicated that some children who initially failed to start school due to financial constrains were able to do so due to the BEAM programme through community involvement. Thus access to education assistance improved. However, the implementation of BEAM had its own share of problems, thus limiting its effectiveness.
\end{abstract}

Keywords: Policy, implementation, participation, community, beneficiary, Zimbabwe 


\section{Introduction}

In Zimbabwe education enrolment at all levels increased dramatically since independence in 1980 (World Bank Human Development Report 1998). For instance, by 1994 the net enrolment range for primary schools was $81.9 \%$ improving to $93 \%$ in 2002 . However, due to Economic Structural Adjustment Programme (ESAP) adopted by the government in 1991, enrolment figures declined as some children dropped out or even failed to start school. National net enrolment rates at both primary and secondary levels declined somewhat between 1990-7 from $98 \%$ to $93 \%$ for primary and from $63 \%$ to $59 \%$ for secondary schools. Despite the official abandonment of ESAP in 2001 the problem of school dropouts continued due to severe economic hardships compounded by the HIV/aids pandemic, faced by the poorer members of society. During ESAP, Government in response came up with the Social Dimensions of Adjustment (SDA) Programme and established the Social Development Fund (SDF) to finance the programme. Later in 1994, citing the narrowness of the SDF, Poverty Alleviation Action Plan (PAAP) which was wider in approach was formulated, under which falls BEAM. The primary objective of Basic Education Assistance Module (BEAM) was to reduce the number of children dropping out and reach out to children who had never been to school due to economic hardships. Literature on poverty advocates bottom-up participatory approaches to development as a lasting solution to poverty alleviation. BEAM was a community based beneficiary targeting programme which allowed community participation in selection of the neediest children. Thus, the effectiveness of BEAM was measured by an assessment of whether the programme managed to reduce the number of school drop-outs and reach out to children who have never been to school due to economic hardships, through community involvement. This research set out to achieve this using the case of the Glen View/ Budiriro District schools in Harare.

\subsection{Background of the study}

When the Zimbabwe Government adopted The Framework of Economic Reform programme in 1991, there were considerable transitional hardships inflicted on the vulnerable groups namely the disabled, women, children and the aged. Again the removal of subsidies on basic social services like education, health and food resulted in severe hardships for the poorer members of society. Cost recovery in the education sector for example, had disastrous effects on the children from poor families as parents were now required to pay fees, even at primary school level in urban areas (Mwanza, 1999). Generally poor parents were withdrawing children from school because of lack of funds more so as they graduated from primary to secondary school Ministry of Public Service, Labour and Social Welfare (MPSLSW), 1997).

Learning from the experiences of other countries implementing similar programmes, the government of Zimbabwe had anticipated transitory economic difficulties, such as high levels of inflation and unemployment. Based on this assumption, the government in November 1991 introduced the SDA programme to cushion the poor from the social effects of the ESAP. This resulted in the establishment of the SDF in the MPSLSW to coordinate programmes targeting the most vulnerable groups. The vulnerable groups are namely, the disabled, 
women, children and the aged. The SDF had two components namely; direct transfers to support health and school fees payments for poor households, and, employment and training programmes to retrain retrenched workers.

However, in 1994 under the newly initiated PAAP which was broader in focus, Government initiated a review of the SDF due to several problems which were being faced. The system had created arrears which became burdens for the fiscus and school authorities. The Department of Social Welfare also used means testing whereby potential beneficiaries presented themselves to the Department of Social Welfare in order to access the assistance that was provided, but this had its bottlenecks. For those means tested, several problems arose. Firstly, accessing the Department of Social Welfare by the majority of the target beneficiaries was difficulty. Secondly, costs of administering the system were high. Thirdly, targeting of people who deserved the assistance was poor, and finally, there was poor geographic coverage which resulted in few people benefiting.

It is against his background that the Government developed the BEAM. BEAM is mainly focused on improving efficiency and transparency and ensuring speedy delivery in Government education assistance to vulnerable children. Of particular importance is also the role of communities in the targeting and selection procedures where communities are responsible for targeting beneficiaries through Community Selection Committees (CSC) that are established by the communities themselves.

Since establishment in 2001, BEAM budgetary allocations rose in nominal terms over the years as shown in Table 1 below:

Table 1. BEAM annual allocations from $2001-5$

\begin{tabular}{|l|l|}
\hline YEAR & ALLOCATION \\
\hline 2001 & $\$ 300$ million \\
\hline 2002 & $\$ 588$ million \\
\hline 2003 & \$1 billion \\
\hline 2004 & $\$ 3.5$ billion \\
\hline 2005 & $\$ 190$ billion \\
\hline
\end{tabular}

Source: BEAM $2001-5$ Reports

According to the MPSLSW Status Report (2005) the allocations were mainly influenced by increases in the incidents of poverty in both numbers and intensity, the general increase in 
school fees, lives and high operational costs. However, the substantiality of the increases over the years was questionable given the prevailing hyperinflationary environment where goods were priced at inflation rates.

Of significance to note was that the (ESAP) was not the sole cause of hardships that were causing children to drop out of school or fail to start school. The problem was also compounded by the Human Immunodeficiency Virus/Acquired Immunity Deficiency Virus (HIV/AIDS). The most affected age range being the 25 to 40 years, implying that the number of the reproductive and economically active adults was reducing leaving children with no support. It was estimated that about a quarter of the population is infected with HIV/AIDS (United Nations Development Programme (UNDP) Poverty Report 2000).

The problem of school dropouts that is, children who were failing to continue with their schooling up to 19 years as per Ministry of Education policy, due to economic hardships, was also being worsened by a highly inflationary environment. For instance, inflation figures rose to $585,8 \%$ by December 2005. Save for 2004, year on year inflation had been on the increase in the past 5 years (Table 2).

Table 2. Year on year inflation rate from $2001-5$

\begin{tabular}{|l|l|}
\hline YEAR END & INFLATION RATE (\%) \\
\hline December 2001 & 116.5 \\
\hline December 2002 & 198.9 \\
\hline December 2003 & 598.7 \\
\hline December 2004 & 132.7 \\
\hline December 2005 & 585.8 \\
\hline
\end{tabular}

Source: Central Statistics Office (CSO)

It was against this background of a hyperinflationary environment that the expenditure basket for a low income urban family for six rose to a range between $\mathrm{Z} \$ 16-21$ million for the month of November 2005 (The Herald 11 January 2006). At the time of completion of this study, the study, the Tripartite Negotiation Form had not yet agreed on minimum wage figures. However, the operational minimum wage figure for domestic workers for instance, stood at Z\$800 000 per month for 2005 (The Herald August 2005). The situation left most consumers restricted to buying purely basic commodities and unable to raise school fees for their children. 
The Ministry of Education also announced sharp school fees increases up to $1000 \%$ for 2005. The increases also came against the backdrop of the Governments' Operation Restore Order, an undertaking which purported to target illegal dwellings and structures and to clamp down on alleged illicit activities (United Nations (UN) Report 2005). The operation resulted in some breadwinners losing their livelihood options in the form of vending and other informal sector businesses. According to the UN Report (2005) on Operation Restore Order, an estimated 700000 people in cities across the country lost their homes, sources of livelihood or both. This also likely increased the number of school dropouts.

\section{Literature Review and Conceptual Framework}

Sabbatier (1993) conceptualized policy implementation from the perspective of the top-down and the bottom-up approaches. However, since the 1970s there has been a fundamental shift from "dependency" and interventionist" theories in search for systemic alternatives; a result of development agencies realizing that the theories of development followed since the 1960s had not been successful. "Participation" has now become the hallmark of sustainable development, which a general shift form prescriptive "top-down" to participatory "bottom-up" approaches to development. The key word in the new vision is participation by all beneficiaries of development programmes: "putting people at the centre" (UNDP 1998).

A wide variety of interpretation is associated with the concept of popular participation. Lisk (1985), after studying a number of developing countries observed that the interpretation of popular participation in a practical content varies considerably from one country setting to another, and may even vary between different regions within the same national entity. Broadly speaking it may range from the token involvement of people, indirectly in the formal decision-making process to autonomous decision making by popular organizations at the local level. It can include co-operation between decision makers and those affected by their actions, without any formal surrender of power to participants, although these may be allowed to modify decisions in order to retain their cooperation. In another form, participation can concede to participants a share of formal power varying from the right to impose temporary or permanent vetoes, to rights to joint or sole decision making. Furthermore, effective communication can be obtained by negotiation between power-holders and representation groups within society. Lisk therefore suggests that because of these differences in interpretations and practices, the concept could, perhaps best be examined in a location - specific context in relation to existing political and socio-economic structures as well as cultural characteristics, all of which combine to determine the nature and scope of participation as an agent of development.

However, a United Nations publication (UNECA 1975) argues that there are basically three ways of viewing popular participation in development, namely, "mass sharing of the benefits of development; mass contribution to the development; and mass decision making in development." Makumbe (1996) notes that popular participation is therefore being viewed as both a goal of development which requires that national resources and opportunities be equitably distributed, and as a way of facilitating and energizing development efforts by means of popular involvement in developmental decision making. 
Makumbe (1996) and Lisk (1985) view beneficiary participation as only being meaningful for the masses if there are effectively involved at the various levels of the development process. For example, popular participation is considered severely limited when the masses are being merely asked to choose between alternatives initially selected by bureaucrats. The limitation of participation becomes more evident under circumstances when none of the alternatives proposed by bureaucrats meets the expectations of the masses, or fail to address what the masses may feel are their felt needs.

The UN publication (UNECA 1975) further argues that mass participation in decision making for development constitutes a critical element which distinguishes "passive" form "active" participation. Accordingly, a more comprehensive view of decision making process involves three stages: defining the situation requiring a decision; choosing the preferred alternative and evaluating the consequences of the action taken. According to the UN (1975), of these three stages, the first may well be the most important, since the way in which a problem situation is defined not only determines and possible alternative solutions but usually tends to restrict the number of relevant choices. If the people are not involved at the first stage, their participation may be limited to merely ratifying what has been determined for them.

Makumbe (1996) also notes that equally crucial to the development process is the people's participation in the evaluation process. This will enable the people to identify the constraints or problems associated or brought about by their previous decisions and may significantly influence their decisions.

Powell (1988) also argues that active participation in development requires that the community or the beneficiaries are fully involved in the whole process, from design to implementation of the programme. The community tends to be actively involved in those programmes that they have contributed to at each and every stage - design, planning, implementation and evaluation. Passive participating in when the community is expected to simply join in at the implantation stage. BEAM confirms Powell's assertion. For BEAM, only the project implementation is a responsibility of the community. The CSC is the implementing agent that, on behalf of the communities carries out selection of the beneficiaries. The District Education Officers form the link between CSCs, the local authorities and the Project Management Unit(PMU) at the MPSLSW.

Thus active participation goes beyond mere choice - making from among predetermined alternatives, while passive participation largely pertains to such choice-making and even manipulation of the masses by those who will have made the critical decisions in the first place.

Another aspect of participatory development is the concept of "direct" and "indirect" participation. The two terms are closely linked to the terms active and passive participation discussed above. The UN publication mentioned above argues that direct participation in decision-making for development involves physical interaction between those persons in whom society has vested the authority to make decisions and the people affected by those decisions. However, Makumbe (1996) argues that under normal circumstances, this form of 
participation is quite feasible at the local level but quite difficult if not impossible to achieve at higher levels. There can be physical interaction without the opportunity for the people or their representatives to make meaningful informed decisions. This is particularly so in most of Africa's rural communities where the bureaucrat is often "king" (Makumbe 1996).

However, despite the wide variety of interpretations associated with the concept, for the purpose of this study popular participation in development projects should be broadly understood as the active involvement of people in the making and implementation of decisions at all levels and forms of political and socio-economic activities. More specifically, in the context of planning poverty alleviation programmes like BEAM, participation relates to the involvement of the broad masses of the people in the choice, execution and evaluation of the programme. BEAM is paradigm shift where there is a change from dealing with one child and family at a time to collaborative action involving service providers, communities and recipients themselves.

It is within the framework of the participatory bottom-up approach that the analysis of the effectiveness of BEAM as a poverty alleviation strategy was made.

\section{Analysis of results}

\subsection{Rate of school dropouts}

Out of a total of five school heads in the district, two revealed that they had experienced school dropouts due to financial constraints from 2001-5. This confirmed the World Bank Development Indicators (2000) findings on the Zimbabwe education system. The World Bank noted that although the education enrolment at all levels increased dramatically since independence in 1980, with the adoption of ESAP in 1991 enrolment figures declined at all levels due to economic hardships. National net enrolment figures declined from $98 \%$ to $93 \%$ and form $63 \%$ to $59 \%$ for primary and secondary schools respectively from 1990-7. However, despite the official abandonment of ESAP in 2001 the problem of school dropouts was still prevalent as indicated in the respondent schools above due to persistent economic hardships compounded by the HIV/AIDS pandemic. It can be concluded that BEAM was being less successful in its primary objective of reducing the number of school dropouts.

The problem of school dropouts was also aggravated in 2005 by the government's Operation Restore Order. Thousands of those who used to work in the informal sector lost their livelihoods as a result of the crack down on flea markets, tuck shops, vending stalls and urban agriculture resulting in some breadwinners failing to keep their children in school. The UN inter-agency working group reported that school enrolment may have dropped by $25 \%$ following the Operation (UN Report 2005). Thus it can also be concluded that some of government's macro-economic policies were working against the primary objective of BEAM. 
3.2 BEAM beneficiaries in the Glen View/Budiriro District from 2001-5

Table 3. BEAM beneficiaries per respondent school from 2001-5

\begin{tabular}{|l|l|l|l|l|l|l|}
\hline SCHOOL & $\mathbf{2 0 0 1}$ & $\mathbf{2 0 0 2}$ & $\mathbf{2 0 0 3}$ & $\mathbf{2 0 0 4}$ & $\mathbf{2 0 0 5}$ & TOTALS \\
\hline A & 52 & 65 & 87 & 73 & 201 & 374 \\
\hline B & 244 & 214 & 175 & 142 & 314 & 1089 \\
\hline C & 50 & 55 & 142 & 25 & 223 & 455 \\
\hline D & 101 & 54 & 42 & 28 & 348 & 575 \\
\hline E & 54 & 59 & 65 & 111 & 120 & 289 \\
\hline TOTALS & $\mathbf{5 0 1}$ & $\mathbf{4 7 4}$ & $\mathbf{4 7 1}$ & $\mathbf{3 7 8}$ & $\mathbf{1 2 0 6}$ & $\mathbf{2 7 8 0}$ \\
\hline
\end{tabular}

Source: Compiled from research data

Table 1 shows that since the inception of the BEAM programme in 2001 not less than 25 pupils per respondent school benefited annually over the five years, with respondent $\mathrm{E}$ having the least number of total beneficiaries and respondent $\mathrm{B}$ having the most. The number of beneficiaries per school also fluctuated annually. The number of beneficiaries annually was determined by the school's fee structure against BEAM allocation for that particular year. There could be an increase or a decrease of beneficiaries. However, 2005 experienced the highest number of beneficiaries per respondent school and thus the highest annual District over the five years (Graph I).

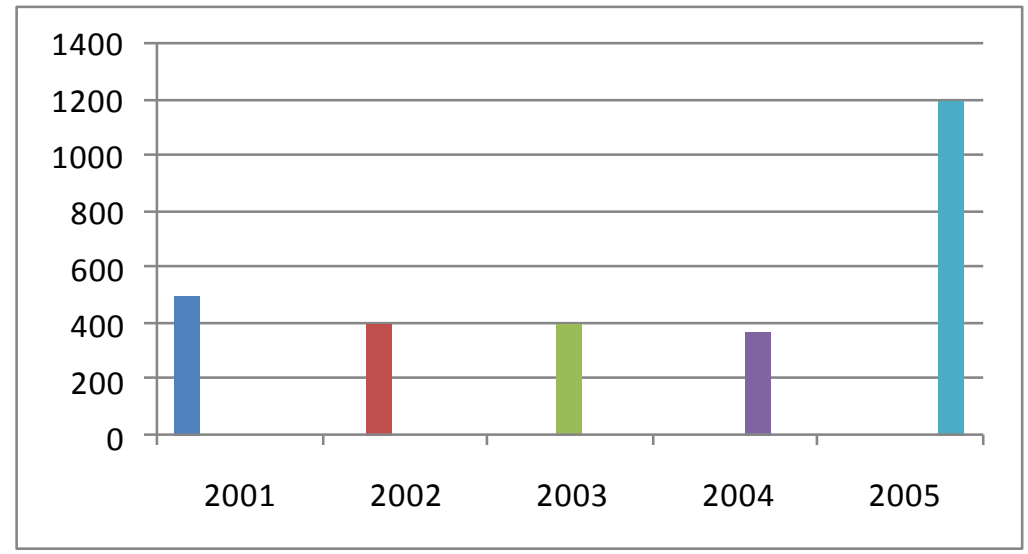

Graph 1. Trend in total annual BEAM beneficiaries in the respondent schools 
Graph 1 shows that the total number of beneficiaries annually steadily declined in the respondent schools over the five years with 2005 experiencing a phenomenal increase. The decline can be explained in terms of the relationship between a school's fee structure and the BEAM allocation to the school. According to the respondent school heads the number of BEAM beneficiaries annually was determined by the school's BEAM allocation and the school's fee structures. This was also confirmed by the BEAM National Coordinator who pointed out that a low fee structure supported more children out of a given allocation than would a high fee structure. The hyperinflationary environment over the years necessitated school fees hikes in the various schools. The national BEAM budgetary allocations over the five years had however not been consistent with the ever increasing high fees and levies charged at the various schools with the aim of keeping pace with the hyperinflationary environment. For instance, in 2004 some schools across the country hiked school fees during the course of the year by $1000 \%$ against a backdrop of Zimbabwe's unprecedented spiraling inflation of around 600\% as at January 2004. In spite of the BEAM programme estimated expenditure being prepared using incrementalism in most cases and the rate of inflation being added, respondents pointed out that BEAM had no supplementary budget to cater for further inflation and school fees hikes during the course of the year. The decline in the number of beneficiaries over the years was an indication of BEAM's failure to reduce the number of school dropouts.

The 2005 increase in the number of beneficiaries was facilitated by a huge BEAM programme financial allocation necessitated by the challenges faced in 2004. According to the 2005 first month BEAM Report, allocations were mainly influenced by increase in the incidents of poverty in both numbers and intensity and the general high increases in school fees, levies and high operational costs due to a hyperinflationary environment. The projected beneficiaries figure for 2005 was anticipated to increase by 1, 9\% compared to 2004. Thus the budgetary allocation was increased from the $2004 \mathrm{Z} \$ 3.5$ billion to a whooping $\mathrm{Z} \$ 190$ billion in 2005 and number of beneficiaries increased from 310363 in 2004 to 888989 at national level (Table 1).

\subsection{BEAM national budgetary allocation 2001-5}

Table 4. BEAM national annual budgetary allocations and beneficiaries

\begin{tabular}{|l|l|l|}
\hline YEAR & TOTAL ALLOCATION & NO. OF BENEFICIARIES \\
\hline 2001 & \$300 million & 595298 \\
\hline 2002 & \$580 million & 865761 \\
\hline 2003 & \$1 billion & 588817 \\
\hline 2004 & \$3.5 billion & 310363 \\
\hline
\end{tabular}




\begin{tabular}{|l|l|l|}
\hline 2005 & $\$ 190$ billion & 888989 \\
\hline TOTAL & $\$ 195 \mathbf{3 8 0} 000 \mathbf{0 0 0}$ & $\mathbf{3 2 4 6} \mathbf{2 2 8}$ \\
\hline
\end{tabular}

Source: BEAM 2002-5 Reports

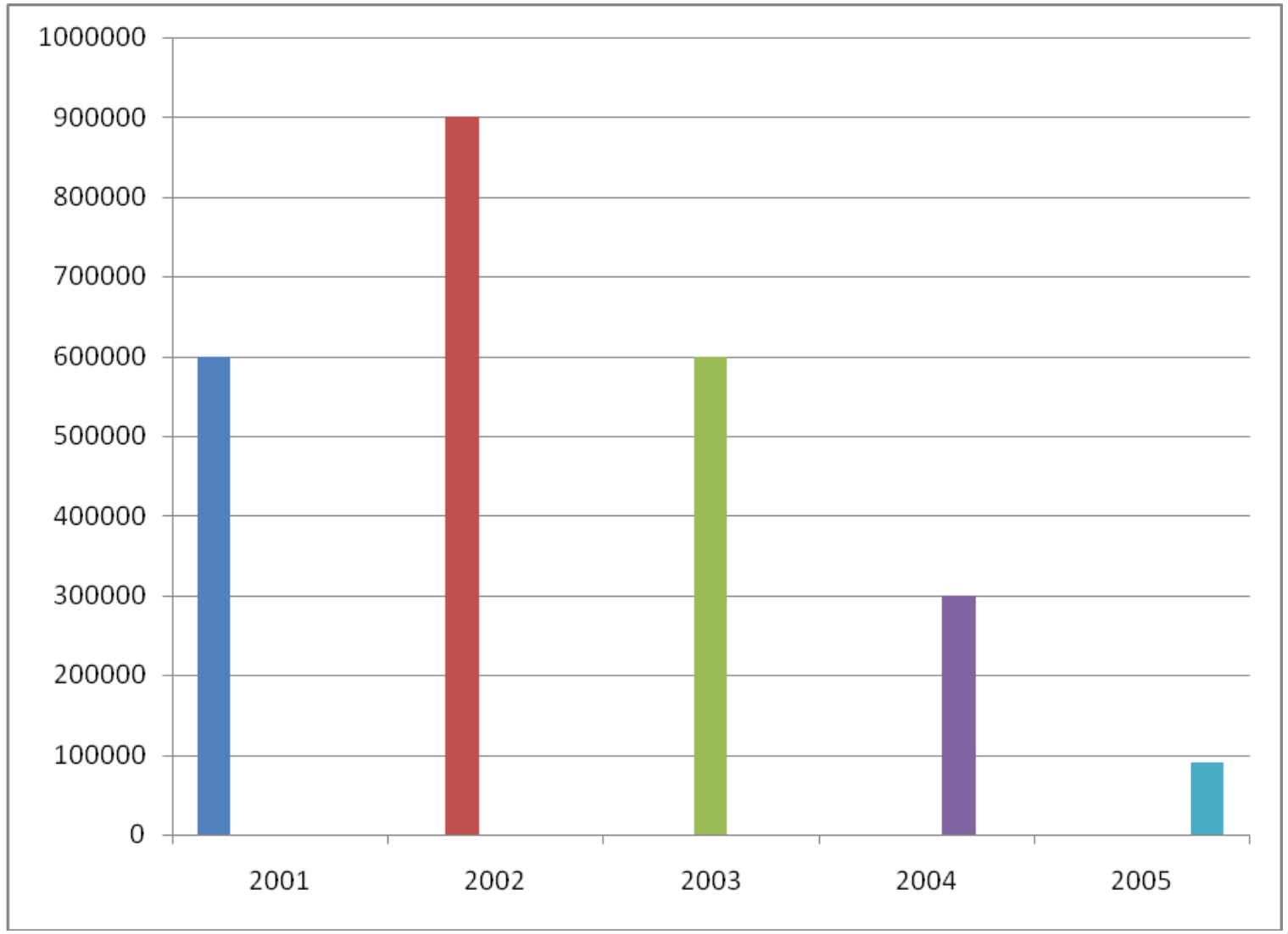

Graph 2. Trend in the number of BEAM beneficiaries nationwide

Table 2 shows BEAM national annual budgetary allocation and beneficiaries over the five years while Graph 2 shows the trend in the number of beneficiaries. The graph shows a decline in the number of beneficiaries annually from 2002-4 and a tremendous rise in 2005 . Thus, the national pattern more or less matches the Glen View/Budiriro district sample findings.

\subsection{Adequacy of BEAM funds per student}

While none of the respondent school heads received the allocations as very adequate, one felt that the allocations were just adequate and the remaining four felt that they were not adequate. Mixed sentiments were also expressed by the respondent CSC members regarding the extent to which the BEAM allocations were alleviating poverty (Table 5). 
Table 5. CSCs' perceptions of BEAM assistance

\begin{tabular}{|l|l|l|l|}
\hline $\begin{array}{l}\text { LEVEL OF } \\
\text { ASSISTANCE }\end{array}$ & FREQUENCY & PERCENTAGE & $\begin{array}{l}\text { CUMULATIVE } \\
\text { PERCENTAGE }\end{array}$ \\
\hline A big way & 11 & 73 & 73 \\
\hline A small way & 4 & 27 & 100 \\
\hline No way at all & 0 & 0 & 100 \\
\hline TOTAL & $\mathbf{1 5}$ & $\mathbf{1 0 0}$ & $\mathbf{1 0 0}$ \\
\hline
\end{tabular}

While none of the respondents felt that BEAM had alleviated poverty in no way at all, a significant $73 \%$ felt BEAM had alleviated poverty in a big way and the remaining $27 \%$ was of the opinion that BEAM was helping in a small way.

The respondent school heads and CSC members who perceived BEAM funds as inadequate cited various reasons. Firstly, after the CSCs' ranking of potential beneficiaries according to their perception of levels of vulnerability, some deserving beneficiaries are left our when the funds allocated per school have been exhausted. Such children could fail to attend school and thus became dropouts. Besides, BEAM funds only catered for tuition, levy and examination fees, a fact confirmed by Cde July Moyo, the then Minister of the MPSLSW in his press statement on 30 January 2001 on the launch of BEAM programme. No provision was made for other essentials like books, uniforms and school projects approved by the SDA/Cs which were more expensive. Respondents pointed out that students who failed to raise funds for school projects were sent away by the SDA/Cs who were running schools, in an effort to encourage them to pay. Eventually the poor parents and guardians would have to find means and ways of raising the required amounts to supplement the BEAM allocations.

The inadequacy of the BEAM funds was also echoed by the chairman of the current Parliamentary Portfolio Committee on Education, the Honourable Member of Parliament (MP) Fedelis Mhashu in a press statement to the Daily Mirror on 25 November 2005, where he urged the government to increase financial resources for the BEAM. Gweru Urban District Aids Action Committee secretary, Shangwa Mavesera also shared the same sentiments. Mavesera also cited the inadequacy of the programme in its negation of children who were orphaned during the course of the year since BEAM's eligible beneficiaries were only selected at the beginning of the year. Mavesera was also concerned with BEAM's lack of a supplementary budget.

Thus it is fair to conclude that while BEAM was successful in enabling some children who had never been to school due to financial constraints to start school; it was unable to keep some of them in school due to its inadequacy resulting in possible dropouts. 


\subsection{Disbursements of BEAM funds to schools}

While none of the respondent schools had experienced timeous disbursements of funds all the time, two had experienced late disbursements all the time, while the remaining three have had erratic disbursements. These findings were consistent with the 2003 and 2004 BEAM Reports findings. According to the 2004 BEAM activities calendar for instance, payment of the third term fees to schools was schedules for the first week of September. However, the Report submitted that third term payments to schools were effected during the month of November due to a number of problems faced by the PMU.

Firstly, the chaos which was being experienced in the financial sector at the time - bank closures and change of school accounts played havoc with the transfer of money between the fund and schools resulting in delays. In addition, during the period July to October problems were experienced with two Computer Programme units, on which the Zimbank and Pay-Net programmes were installed, a problem that was rectified by the first week of November.

Over the above, there was a host of other problems experienced by the PMU over the years. According to the BEAM reports the major challenges included the ever increasing high fees and levies (made after budgetary allocations), overwhelming demand due to increasing economic hardships compounded by HIV/AIDS, outdated computers, late submissions and understatement of enrolment figures by some schools to enable computation of allocations, some CSCs not submitting claims in time or not submitting at all due to errors. The PMU also lacked adequate staff for instances, according to the 2004 BEAM Report the PMU operated without a substantive Data-base officer for the whole year. The National Aids Council contribution, another revenue source for BEAM, was often received as late as September when third term payments to schools had already been done, thus aggravating the problem of inadequacy of funds.

Thus it can be concluded that BEAM funds disbursements were erratic due to a combination of problems cited above. The problems emanated from the schools and the Department of Social Welfare as well as other players like banks.

\subsection{Community participation in the BEAM process}

All the respondents (school heads, CSC members, and MPSLW official) perceived the implementation of BEAM as a responsibility of the community. According to the BEAM Operational Manual, the community is responsible for the selection of the BEAM CSCs through elections and the nomination of beneficiaries using selection criteria outlined in the Manual. The names of the nominated children together with supporting documents should be submitted to the CSC at the relevant school for selection. After the selection of beneficiaries, a list with the names of all selected children would be drawn up and submitted to the District Education Officer (DEO).

The provisions of the Operation Manual on the role of the community in the BEAM process were to a large extent consistent with the findings in the Glen view/Budiriro District. There are slight differences in matters of procedure (Table 4). 
3.6 Selection of CSC members

Table 6.CSC selection procedures

\begin{tabular}{|l|l|l|l|}
\hline $\begin{array}{l}\text { SELECTION } \\
\text { PROCEDURE }\end{array}$ & FREQUENCY & PERCENTAGE & $\begin{array}{l}\text { CUMULATIVE } \\
\text { PERCENTAGE }\end{array}$ \\
\hline Election & 13 & 77 & 100 \\
\hline Appointment & 2 & 13 & 100 \\
\hline Other & 0 & 0 & 100 \\
\hline TOTAL & $\mathbf{1 5}$ & $\mathbf{1 0 0}$ & $\mathbf{1 0 0}$ \\
\hline
\end{tabular}

Table 4 shows that $77 \%$ of the respondent CSC members came into office through election by members of the community $13 \%$ of the respondents were appointed by the community and were in office for the second year running. The respondents were appointed by the community due to their popularity with the people and their approved leadership skills in the community. This was however inconsistent with the provisions of the Operational Manual where CSC members had to be elected. Although the MPSLSW stipulated procedures for CSC selection, these can be slightly changed by the community where appropriate. However, all the respondent CSC members revealed that they were very satisfied with the way the CSC members were selected. They also confirmed that there were no incidents where external pressure influenced the selection of either CSC members or beneficiaries.

\subsection{The BEAM beneficiaries' selection criteria}

Although the selection criteria is a product of the Department of Social Welfare, the respondent CSC members felt that even though the community was not consulted in coming up with the criteria, the CSCs had more discretion in the selection of beneficiaries through the "Other (Specify)" provision in the selection criteria. Depending on available funds, the CSC ranked applicants according to the extent of vulnerability and allocated funds accordingly. The ranking of the selection criteria at a school could differ from year to year depending on the perceptions of the CSC in office that particular year. 
3.8 Clarity of the beneficiaries' selection criteria

Table 7. Respondents' perception of the clarity of the beneficiary selection criteria

\begin{tabular}{|l|l|l|l|}
\hline CLARITY & FREQUENCY & PERCENTAGE & $\begin{array}{l}\text { CUMULATIVE } \\
\text { PERCENTAGE }\end{array}$ \\
\hline Very clear & 15 & 75 & 75 \\
\hline Slightly vague & 4 & 20 & 95 \\
\hline Not clear at all & 1 & 5 & 100 \\
\hline TOTAL & $\mathbf{2 0}$ & $\mathbf{1 0 0}$ & $\mathbf{1 0 0}$ \\
\hline
\end{tabular}

Table 7 shows that $75 \%$ of the respondents (school head and CSC members) perceived the BEAM selection criteria as very clear, $20 \%$ viewed it as slightly vague and the remaining five percent not clear at all. The respondents who cited lack of clarity of the BEAM selection criteria cited various problems.

Firstly, some categories were too broad and not well understood for instance, breadwinner not gainfully employed, and thus subject to different interpretations by different people. While the "Other (specify)" provision in the selection criteria also gave discretion to the CSCs in the selection process, it could also be subjected to abuse resulting in some undeserving children being included in the programme.

In addition, most people had a misconception that all pupils with deceased parent(s) deserved assistance regardless of the fact that the guardian or remaining parent could afford the needs of the orphan. Thus less deserving children could benefit by virtue of them being orphans yet the guardian or remaining parent would, in some instances, be receiving pensions of the deceased on behalf of the bereaved children. This disadvantaged other eligible beneficiaries who might have been left out due to inadequacy of funds since, according to respondents; orphans were given top priority in the ranking of potential beneficiaries.

It can be concluded that the selection criteria was to al large extent clear. To a lesser extent, some loosely stated categories made it susceptible to abuse as these could be subjected to different interpretations resulting in undeserving children benefiting from the programme.

\subsection{Transparency and accountability in the selection of beneficiaries}

To ensure transparency and accountability in the BEAM beneficiaries' selection process, the MPSLSW policy and procedures require that all CSCs publicize names of all BEAM beneficiaries on school notice boards annually. However, findings in the Glen View/ Budiriro District were inconsistent with this procedural requirement. All the respondent schools had not publicized the names for 2005. The respondent schools heads pointed out that parents and guardians did not want to be known that they were BEAM beneficiaries. They felt socially 
stigmatized because BEAM was associated with poverty. They wanted to benefit privately and did not want their children paraded at school assemblies or mentioned in class that they were BEAM beneficiaries. These findings were consistent with the views of the BEAM National Coordinator at MPSLSW. The findings were also confirmed in an MPSLSW Circular dated 2 April 2005 expressing the Ministry's concern at some of the CSCs' failure to adhere to this accountability and transparency measure and advising them to do so.

The community was also responsible for the validation process of selected beneficiaries. According to the BEAM Operational Manual, after the selection of beneficiaries, the CSC would convene a meeting to inform the community on the final list of selected children. If there were any perceived irregularities, provision for appeals by aggrieved parties was catered for through the Councilor, the DEO and parents associations in the urban areas. In the rural areas parallel structures were also used. However, although various respondents cited incidents of grievances being raised by the community regarding beneficiary selection at school level, the BEAM National Coordinator pointed out although the PMU was aware of such allegations, nobody had been forthcoming to report corruption in a meaningful way for fear of reprisal especially through witchcraft, since community members were quite aware of who was who in the community.

Therefore, even though the MPSLSW had put in place accountability and transparency measures in the selection of beneficiaries, they were not effective since they were not been adhered to by some of the CSCs. Besides, those who cited corruption were not brave enough to stand up to the end to prove their cases. Thus, it can be concluded that accountability and transparency in the selection process of BEAM beneficiaries was problematic.

\subsection{Impact of community involvement in accessing BEAM by beneficiaries}

A significant majority (80\%), of the respondents (school heads and CSC members) agreed that the involvement of the community in the selection of beneficiary children was of great use citing various reasons. Firstly, if the task of identifying and selecting needy pupils was left to school heads, they would not have managed to come up with the most deserving beneficiaries on their own. The task could be best carried out by the CSC members who lived in the community and were in a better position to know the status of families, their financial needs and which children were attending school and which ones were not. As a result, children who initially failed to start school due to financial constraints were now included in the programme through community based knowledge. Besides, the process became democratic and it reduced elements of corrupt tendencies like favouritism and nepotism as the true status of a beneficiary could be easily verified by the community.

A minority (20\%) of the respondents felt that the involvement of the community was of very little use since some CSC members were subjective in selecting the needy pupils. The respondents pointed out that at times some of the CSC members' or their friends' children benefited from the programme regardless of whether they fell in the most deserving criteria or not. Incidents of discrimination could also not be ruled out under such circumstances. Thus while community involvement in the BEAM process contributed towards improved 
access to the programme by beneficiaries, elements of corruption could not be ruled out.

\subsection{Problems encountered by the CSC in the selection of beneficiaries}

Respondent CSC members cited a number of problems. The demand for assistance exceeded the school's budgetary allocation, thus some deserving children were left out. Due to the overwhelming demand the available funds could not cater for all applicants. Thus the CSC members had to rank applicants according to the extent of vulnerability and allocated funds accordingly. Those lower in the ranking failed to get assistance due to the inadequacy of the funds. In some instances the selection process engendered enmity between the CSC members and some community members where children who benefited in the previous year were dropped the following year due to the inadequacy of the funds and more deserving pupils would have replaced them. The community members whose children were dropped alleged hatred and discrimination as they failed to understand why their children were dropped from the programme.

The selection procedure also became complicated where categories were vague. This resulted in the distortion of the selection criteria by some CSC members as they failed to agree on interpretations. Complacency and sometimes ignorance on the part of parents or guardians also complicated the CSCs' task. Some parents and guardians, grandmothers and child headed families in particular, failed to re-apply for children already on the programme for renewal annually. The CSC proceeded to work on wrong figures. When deadlines passed, these deserving children could no longer be re-admitted in the programme, a situation which the CSC would have no solution to.

\subsection{Problems encountered by the schools in the BEAM implementation}

Respondent school heads pointed out quite a number of problems they faced with the BEAM programme. The erratic disbursement of funds left school heads in a dilemma as to who the recipients for that year were. They could not call on the selection committees to determine the beneficiaries since they were ignorant of how much their school were to be allocated. Over the years, funds were also inadequate to cover all the deserving children and for those who benefited, the funds were unable to cater for all the essentials like books, uniforms and fees increments during the course of the year. Thus the deserving children did not benefit in their entirety and those who did benefit had to be sent away in some instance for shortfalls and other payments which were not covered by BEAM, for instance, building fund for school projects approved by the SDAs/Cs.

The BEAM process also involved a lot of paper work as submission of application forms was done annually even by those who were already in the programme. This observation was consistent with the Chairman of the then Parliamentary Portfolio Committee on Education, Honourable MP Fidelis Mhashu's sentiments in the Daily Mirror (25 November 2005) who queried the rationale behind the re-submission of forms annually by children already in the scheme. However, some respondents maintained that the status of children may change from year to year or they might change districts. The workload was further compounded by the paper work of secondary schools' beneficiaries who were catered for by the primary schools 
in the same catchment areas as the secondary schools.

\section{Conclusions and recommendations}

\subsection{Rate of dropouts}

From the results of the study it can be concluded that BEAM was less successful in achieving its primary objective of reducing the number of school dropouts. Save for 2005, the general trend both at Glen view/Budiriro District and national level, in the number of beneficiaries was of a decline. BEAM annual allocations failed to match with the ever increasing high fee structures in the various schools resulting in some potential beneficiaries being left out. Hence poor parents and guardians pumped out money to either supplement the BEAM allocations or paid for the children all the way on their own culminating in possible school dropouts. BEAM also suffered a serious setback due to the effects of the government's Operation Restore Order which resulted in thousands of those formerly employed in the informal sector losing their sources of livelihoods and thus failing to keep their children in school. Such a situation exacerbated the problem of school dropouts.

It is also fair to conclude that to a lesser extent, BEAM was successful as some children who initially failed to attend school due to financial constraints managed to start school.

By and large these findings confirm the justification of the study that in policy implementation, very often adopted policies have not produced the desired results, proving wrong the notion held over the years by policy makers and political scientists that once policies are enacted they will simply be carried out to achieve desired goals.

\subsection{Adequacy of BEAM funds per student}

The grant per student was inadequate and fell short of expectations in so far as alleviating the plight of poor households was concerned. The inadequacy of BEAM lay in that after the CSCs' ranking of potential beneficiaries according to levels of vulnerability, some deserving children were left out when the allocated funds were exhausted. Thus deserving children were not assisted in their entirety.

BEAM funds also catered for tuition, levy and examination fees only. No provision was made for other essentials like books, uniforms and school projects approved by the SDAs/Cs which were more expensive. As a result, students who failed to raise funds for school projects were sent away by the SDAs/Cs who were running schools, in an effort to encourage them to pay. Eventually the poor parents and guardians would have to find means and ways of raising the required amounts to supplement the BEAM allocations. Thus the poor could engage in perverse coping mechanisms against poverty like prostitution or other extremes like selling everything they had and become poorer, in order to send their children to school.

The inadequacy of BEAM also lay in its lack of a supplementary budget. Thus, eventual school fees hikes during the course of the year were not catered for, leaving the selected beneficiaries with balance of payments to be met by their parents and guardians. Children who were orphaned during the course of the year were also not covered since BEAM's eligible beneficiaries were only selected at the beginning of the year. 


\subsection{Disbursements of BEAM funds to schools}

The disbursement of BEAM funds to schools over the years was erratic. The major challenges faced included outdated computers, late submission and understatement of enrolment figures by some schools to enable computation of allocations, some CSCs not submitting claims in time or not submitting at all due to errors. The chaos that once hit the financial sector also resulted in some bank closures thus affecting the transfer of money between the fund and schools. The National Aids Council contribution was also coming late. The PMU was also operating with inadequate staff.

\subsection{Community participation in the BEAM process}

Going by the conception of participation in this study it can be concluded that communities owned the BEAM process to a lesser extent. Participation in this research is perceived as the involvement of beneficiaries in development projects at all levels of the project cycle that is, from problem identification, project designing, implementation and evaluation. In the BEAM process the community only featured at the implementation stage while the other stages were a prerogative of the Department of Social Welfare and the Ministry of Education and Culture. This falls short of full participation.

\subsection{Clarity of the selection criteria}

It can be concluded that the selection criteria was to a large extent clear. To a lesser extent, some loosely stated categories for instance, the "Other (specify)" provision, while giving discretion to the CSCs, could be subjected to abuse. Broad or vague categories could also be subject to different interpretations resulting in undeserving children benefiting from the programme.

In relation to the selection criteria, it can also be concluded that accountability and transparency in the selection criteria of BEAM beneficiaries was problematic. Even though the MPSLSW had put in place measures to that effect, they were not being adhered to by some of the CSCs. The PMU also lacked effective regulation enforcement mechanisms particularly regarding the publicizing of beneficiaries on school notice boards. Those who cited corruption also failed to stand firm as witnesses for the curtailment of corrupt behaviour in the selection process.

\subsection{Impact of community involvement in accessing BEAM beneficiaries}

It can be concluded that community involvement in the BEAM process contributed immensely towards making the programme accessible by potential beneficiaries since some children who initially failed to attend school due to financial constrains were catered in the programme due to community involvement. However, some of the CSC members introduced elements of corruption in the selection process thereby rendering the programme subject to abuse in some instances. 
4.7 Problems faced by schools and CSCs in the implementation of BEAM

It can be concluded that both the schools and CSCs had their fair share of problems. Problems faced by schools included inadequacy of funds, late disbursement of funds and work overload as BEAM applications were submitted annually by all selected beneficiaries even those who had benefited the previous year. The work load was also increased by the secondary schools' beneficiaries whose forms were processed by the primary schools in the same catchment areas as the secondary schools.

The CSCs particularly faced problems of dealing with an overwhelming demand for assistance as communities continually faced economic hardships compounded by the HIV/AIDS pandemic. Complacency and ignorance on the part of some guardians and parents made the CSCs task of selecting beneficiaries more challenging as they had to meet deadlines. Distortion of the selection criteria by some of their members also remained a problem they had to continuously grapple with. In some instances the BEAM selection process engendered enmity within communities as expectant parent and guardians failed to get assistance due to the inadequacy of funds, and the CSC members had to bear the brand.

To ensure that BEAM as a participatory approach towards poverty alleviation plays an effective role in the number of school dropouts, the Governments needed to address the issues of inadequacy of funds, late disbursement of funds, an ambiguous beneficiary selection criteria and all the other problematic areas identified in this study.

\section{References}

Books

Anderson J, Public Policy Making. New York: Winston, 1984.

Chisvo, M. A Review of the Social Dimension of Adjustment in Zimbabwe 1990-1994, UNICEF, Harare: 1994.

Dye, T. Understanding Public Policy. New Jersey: Prentice Hall, 1984.

Edwards, G. E. Implementing Public Policy. Washington D. C. Congressional Quarterly Printers, 1980.

Howlett, M. and Ramesh, M. Studying Public Policy. Toronto: Oxford University Press, 1995.

Jenkins C. "Economic Policy Investment in Zimbabwe 1980-1989." Centre for the Study of African Economics. University of Oxford, 1995.

Jenkins, C. and Prinsloo, E. "Inequality among Households in Zimbabwe: An Assessment Using the 1990/91 ICES." Centre for the Study of African Economies.Oxford University, 1993.

Klugman, J. and Helmsing. A. H. Decentralisation in Zimbabwe Human Development, 1995. 
Korteen, D. C. Rudi, K (eds) People-Centred Development: Contributions Toward Theory and Planning Framework. Connecticut: Kumanan Press, 1984.

Lindblom, C. The Policy Making Process. New Jersey: Prentice-Hall, 1980.

Lisk, F. (ed__ Popular Participation in Planning for Basic Needs. Longmead: Blackmore Press, 1985.

Loeweson, R. "The Social Dimension of Structural Adjustment.” Harare: ZIDS, 1991.

Makumbe, J. M. W. Participatory Development, Harare: University of Zimbabwe Publications, 1992.

Mlambo, A. S. The Economic Structural Adjustment Programme. The case of Zimbabwe, 1990-1995. Harare: UZ Publications, 1997.

Mwanza, A. (ed) Social Policy in an Economy under stress: The case of Zimbabwe Harare: SAPES Books, 1999.

Narayan, D. (ed) Empowerment and Poverty Reduction. A Source Book. The World Bank, New York, 2002.

Powell, F. "Training for Participation," in Institute of Cultural Affairs International, Brussels, (ed). Approaches that Work in Rural Development. New York: K. G. Saur, 1988.

Sabbatier, P. A. "Top-down Bottom-up Approaches in Implementation Research" in Michael, C (ed) The Policy Process. A Reader Harvester Wheatsheaf, 1995.

Sachikonye L. "The State and the Union Movement in Zimbabwe. Cooptation, Conflict and Accommodation.” (Unpublished mimeo 1997).

Shadur M._Labour Relations in a Developing Country: A Case study in Zimbabwe. Averbry, 1994.

Reports

CSO Consumer Price Index January 2006.

Constitution of Zimbabwe Amendment No. 17

Government of Zimbabwe Socio-economic Review 1980-1985. Harare: Government Printers.

Government of Zimbabwe Poverty Alleviation Action Plan, 1994.

Government of Zimbabwe Poverty Assessment Study Report, 1997.

MPSLSW BEAM Status Report 2005.

Poverty in Zimbabwe. CSO, 1998.

United Nations Economic Commission for Africa Report. "Decentralisation Practices and Trends in Africa." Addis Ababa: 1989. 


\section{Macrothink}

UN Report on Operation Restore Order, August 2005.

United Nations, Popular Participation in Decision Making for Development. (UN Department of Economics and Social Affairs, New York, 1975).

UNDP Poverty Report, 2000.

UNDP Poverty Report, 2005.

World Bank Human Development Report, 1998, Zimbabwe.

World Bank Human Development Report 1994.

World Bank Social Protection Strategy paper, 1999.

World Bank Development Indicators, 2000.

World Bank Human Development Report 2003, Zimbabwe. 